Notes and Comments

\title{
First report of Diabrotica speciosa (Germar, 1824) and Maecolaspis trivialis (Boheman, 1858) (Coleoptera: Chrysomelidae) in the angel's trumpet Brugmansia suaveolens (Humb. \& Bonpl. Ex Willd.) Bercht. \& J. Presl. (Solanaceae) in Brazil
}

\author{
Primeiro registro de Diabrotica speciosa (Germar, 1824) e Maecolaspis trivialis \\ (Boheman, 1858) (Coleoptera: Chrysomelidae) em trombeteira Brugmansia \\ suaveolens (Humb. \& Bonpl. Ex Willd.) Bercht. \& J. Presl. (Solanaceae) in Brazil
}

\author{
O. C. Bortolotto ${ }^{\mathrm{a} *}$ (D), and J. B. Pazini ${ }^{\mathrm{b}}$ (D) \\ aUniversidade Estadual de Ponta Grossa - UEPG, Campus Uvaranas, Ponta Grossa, PR, Brasil \\ 'Escola Superior de Agricultura "Luiz de Queiroz", Universidade de São Paulo - USP, Piracicaba, SP, Brasil
}

Diabrotica speciosa (Germar, 1824) and Maecolaspis trivialis (Boheman, 1858) are important defoliators of the Chrysomelidae family. The species are polyphagous and have been reported in different crops. For example, soybeans, beans, corn, potatoes, tobacco, and peanuts are D. speciosa hosts (Walsh et al., 2020). Similarly, the genus Maecolaspis has also been reported in some crops, such as legumes (Fabaceae family) (Miwa and Meinke, 2015) and vineyards (Agrain et al., 2016). In Brazil, the occurrence of Maecolaspis is frequently observed in soybean crops (Moscardi et al., 2012); however, information about the host plants of this defoliator is scarce.

In addition to cultivated plants, the occurrence of chrysomelids in toxic plants has also been reported in the literature. In the United States, D. speciosa has been reported in the angel's trumpet Brugmansia arborea (L.) Lagerheim (Solanaceae) (Walsh, 2003). This ornamental plant has medicinal properties (Petricevich et al., 2020) and chemical defense mechanisms against insect herbivory (Arab et al., 2012; Gonçalves et al., 2019). However, some herbivores can develop detoxification strategies that allow the ingestion of toxic plant leaf tissue (Pinto et al., 2016). Therefore, this study aims to record the occurrence of $D$. speciosa and $M$. trivialis associated with the angel's trumpet Brugmansia suaveolens (Humb. \& Bonpl. Ex Willd.) Bercht. \& J. Presl. (Solanaceae) for the first time in Brazil.

Two B. suaveolens trumpet plants were observed in a residential area of Londrina ( $\left.23^{\circ} 17^{\prime} 34^{\prime \prime S}, 51^{\circ} 10^{\prime} 24^{\prime \prime} \mathrm{W}\right)$ in January 2016. The plants were monitored for $5 \mathrm{~d}$ to examine the herbivory (Figure 1), and the insects were later collected. Herbivory was proven by observing the insects damaging the plants for 30 min.d $^{-1}$. Although the level of defoliation has not been quantified, it was observed between $20-40 \%$ of leaf injury. On the other hand, flowers were $100 \%$ injured by chrysomelids. The individuals were then immediately captured using a sweep net. The collected insects were placed in a plastic bag containing cotton soaked with ethyl acetate. The samples were sent to the insect taxonomy laboratory of the State University of Londrina, where the species were identified according Boheman (1858) and Marques (1941) descriptions.

In total, 25 chrysomelids consisting of two species, namely $M$. trivialis ( $n=19$ specimens) and $D$. speciosa ( $n=6$ specimens), were collected. Although $D$. speciosa has already been reported in angel's trumpet in the United States (Walsh, 2003), this is the first record in Brazil, while the genus Maecolaspis is associated for the first time to Brugmansia. The association of herbivores with angel's trumpet has been reported by other researchers. For example, Taylor and Kent (2013) included an unknown species of Brugmansia among the hosts of Acizzia solanicola Kent \& Taylor, 2010 (Hemiptera: Psyllidae). Similarly, Pinto et al. (2020) observed the presence of the leafhopper Alchisme grossa (Fairmaire, 1846) (Hemiptera: Membracidae) in B. suaveolens. In Brazil, Epilachna vigintioctopunctata (Fabricius, 1775)(Coleoptera: Coccinellidae) larvae were also found in B. suaveolens (Casari and Teixeira, 2015). Although the trumpet plants contain tropane alkaloids, which are toxic to insects (Arab et al., 2012), this study suggests that D. speciosa and $M$. trivialis have developed defense mechanisms. Even if the mechanisms are not well understood, it is likely that the plant's alkaloids are ingested and kidnapping, as already evidenced for A. grossa in trumpet plants (Pinto et al., 2016). 

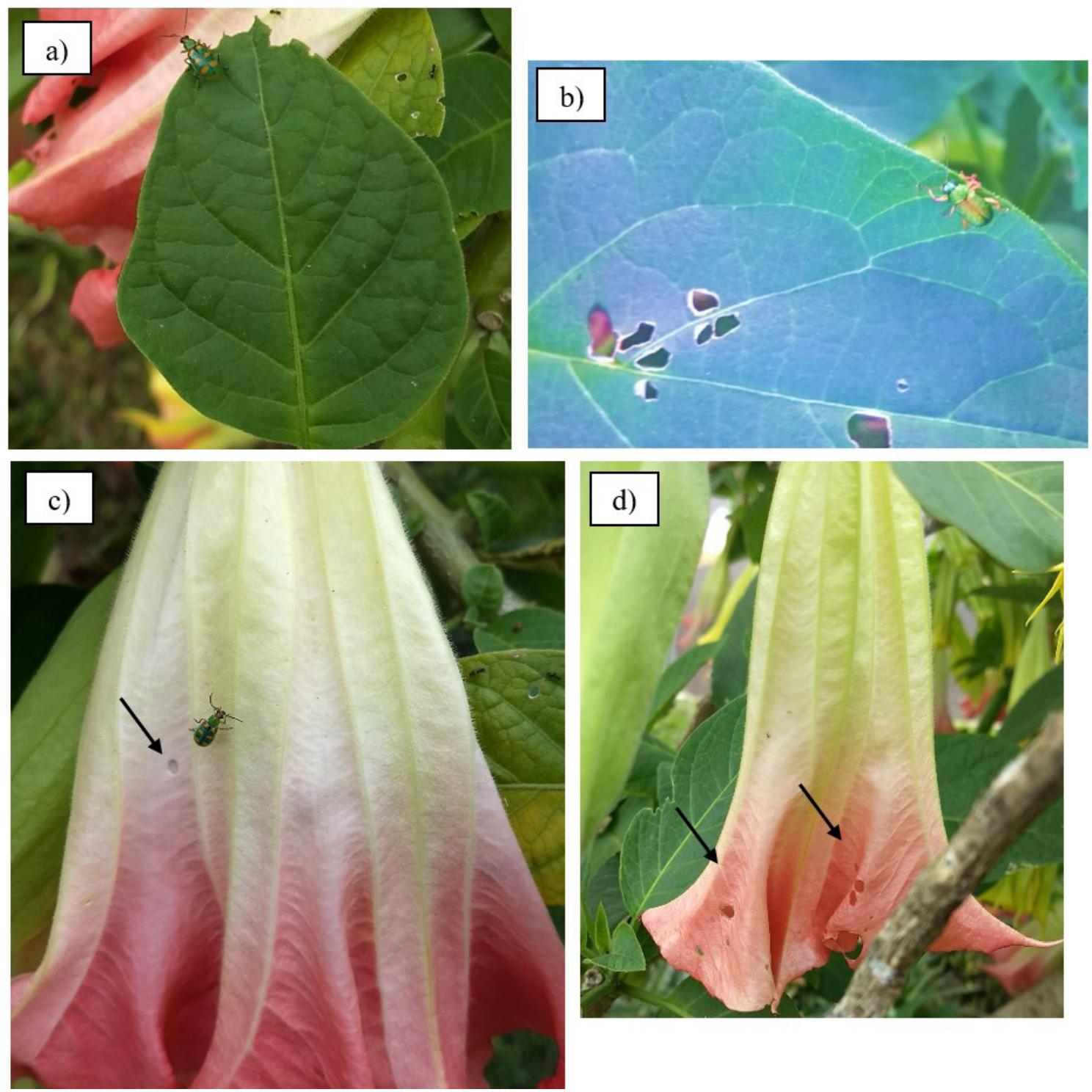

Figure 1. (a) Diabrotica speciosa defoliating Brugmansia suaveolens; (b) Maecolaspis trivialis defoliating B. suaveolens; (c) D. speciosa damaging B. suaveolens flower; (d) B. suaveolens damaged by D. speciosa.

\section{References}

AGRAIN, F.A., CABRERA, N., HOLGADO, M.G. and VICCHI, F.R., 2016 Colaspis caligula, a new species found in association with Vitis vinifera (L.) crops in Argentina (Coleoptera: chrysomelidae). Zootaxa, vol. 4161, no. 2, pp. 228-236. http://dx.doi.org/10.11646/ zootaxa.4161.2.5. PMid:27615925.

ARAB, A., ALVES, M.N., SARTORATTO, A., OGASAWARA, D.C. and TRIGO, J.R., 2012. Methyl jasmonate increases the tropane alkaloid scopolamine and reduces natural herbivory in Brugmansia suaveolens: is scopolamine responsible for plant resistance? Neotropical Entomology, vol. 41, no. 1, pp. 2-8. http://dx.doi.org/10.1007/s13744-011-0001-0. PMid:23950002.

BOHEMAN, C.H., 1858. Coleoptera; species novas descripsit. In: C.A. VIRGIN, ed. Kongliga Svenska Fregatten Eugenies resa omkring Jorden + Vetenskapliga iakttagelser. II. Zoologi. 1. Insecta.
Stockholm: P. A. Norstedt \& Söner, 112 p. [Continued in 1859; total 217 pp., 2 pls.].

CASARI, S.A. and TEIXEIRA, E.P., 2015. Immatures of Epilachna Chevrolat (Coleoptera, Coccinellidae, Epilachninae). Revista Brasileira de Entomologia, vol. 59, no. 2, pp. 113-120. http:// dx.doi.org/10.1016/j.rbe.2015.03.006.

GONÇALVES, G.L.P., CREVELIN, E.J., LIRA, S.P. and VENDRAMIM, J.D., 2019. Effects of Brugmansia suaveolens fractions on Zabrotes subfasciatus (Coleoptera: Chrysomelidae: Bruchinae). Journal of Biopesticides, vol. 12, no. 1, pp. 19-29.

MARQUES, M.A., 1941. Contribuição ao estudo dos crisomelídeos do gênero Diabrotica. Boletim da Escola Nacional de Agronomia, vol. 2, no. 3, pp. 61-117.

MIWA, K. and MEINKE, L.J., 2015. Developmental biology and effects of adult diet on consumption, longevity, and fecundity 
of Colaspis crinicornis (Coleoptera: chrysomelidae). Journal of Insect Science, vol. 15, no. 1, pp. 78. http://dx.doi.org/10.1093/ jisesa/iev062. PMid:26106090.

MOSCARDI, F., BUENO, A.F., SOSA-GOMEZ, D.R., ROGGIA, S., HOFFMANN-CAMPO, C.B., POMARI, A.F., CORSO, I.C. and YANO, S.A.C.A., 2012. Artrópodes que atacam as folhas da soja. In: C.B. HOFFMAN-CAMPO, B.S. CORRÊA-FERREIRA and F. MOSCARDI, eds. Soja: manejo integrado de insetos e outros artrópodes-praga. Brasília: Embrapa, Cap. 4, pp. 213-334.

PETRICEVICH, V.L., SALINAS-SÁNCHEZ, D.O., AVILÉS-MONTES, D., SOTELO-LEYVA, C. and ABARCA-VARGAS, R., 2020. Chemical compounds, pharmacological and toxicological activity of Brugmansia suaveolens: a review. Plants, vol. 9, no. 9, pp. 1161. http://dx.doi.org/10.3390/plants9091161. PMid:32911850.

PINTO, C.F., SALINAS, S., FLORES-PRADO, L., ECHEVERRÍA, J. and NIEMEYER, H.M., 2016. Sequestration of tropane alkaloids from Brugmansia suaveolens (Solanaceae) by the treehopper Alchisme grossa (Hemiptera: Membracidae). Biochemical Systematics and Ecology, vol. 66, pp. 161-165. http://dx.doi.org/10.1016/j. bse.2016.03.015.

PINTO, C.F., TORRICO-BAZOBERRY, D., FLORES-PRADO, L., BUSTAMANTE, R.O. and NIEMEYER, H.M., 2020. Demographic and performance effects of alternative host use in a Neotropical treehopper (Hemiptera: Membracidae). Ecological Modelling, vol. 416, pp. 108905. http://dx.doi.org/10.1016/j. ecolmodel.2019.108905.

TAYLOR, G.S. and KENT, D., 2013. Potential economic pests of solanaceous crops: a new species of Solanum-feeding psyllid from Australia and first record from New Zealand of Acizzia solanicola (Hemiptera: Psyllidae). Zootaxa, vol. 3613, no. 3, pp. 257-273. http://dx.doi.org/10.11646/zootaxa.3613.3.4. PMid:24698916.

WALSH, C.G., 2003. Host range and reproductive traits of Diabrotica speciosa (Germar) and Diabrotica viridula (F.) (Coleoptera: Chrysomelidae), two species of South American pest rootworms, with notes on other species of Diabroticina. Environmental Entomology, vol. 32, no. 2, pp. 276-285. http:// dx.doi.org/10.1603/0046-225X-32.2.276.

WALSH, G.C., ÁVILA, J.C., CABRERA, N., NAVA, D.E., PINTO, A.S. and WEBER, D.C., 2020. Biology and management of pest Diabrotica species in South America. Insects, vol. 11, no. 7, pp. 1-18. http:// dx.doi.org/10.3390/insects11070421. PMid:32650377. 